\title{
Fetal Hemoglobin in Sickle Cell Anemia: Genetic Studies of the Arab-Indian Haplotype
}

\author{
Duyen Ngo ${ }^{1}$, Harold Bae ${ }^{2}$, Martin H. Steinberg ${ }^{1}$, Paola Sebastiani ${ }^{2}$, Nadia Solovieff ${ }^{2}$, \\ Clinton T. Baldwin ${ }^{3}$, Efthymia Melista ${ }^{3}$, Surinder Safaya ${ }^{1}$, Lindsay A. Farrar ${ }^{4}$, Ahmed M. \\ Suliman $^{5}$, Waleed H. Albuali ${ }^{5}$, Muneer H. Al Bagshi ${ }^{6}$, Idowu Akinsheye ${ }^{1}$, Patrick Gallagher ${ }^{7}$, \\ Hong-yuan Luo ${ }^{1}$, David H.K. Chui ${ }^{1}$, John J. Farrell ${ }^{4}$, Amein K. Al-Ali ${ }^{6}$, and Abdulrahman \\ Alsultan 8 \\ ${ }^{1}$ Center of Excellence in Sickle Cell Disease, Department of Medicine, Boston University School \\ of Medicine, Boston, MA \\ ${ }^{2}$ Department of Biostatistics, Boston University School of Public Health, Boston, MA \\ ${ }^{3}$ Center for Human Genetics, Boston University School of Medicine, Boston, MA. \\ ${ }^{4}$ Division of Genetics, Department of Medicine, Boston University School of Medicine, Boston, MA \\ ${ }^{5}$ King Fahad Hospital, Hofuf, Saudi Arabia \\ ${ }^{6}$ Al-Omran Scientific Chair, College of Medicine, King Faisal University, Al-Ahsa, Saudi Arabia \\ ${ }^{7}$ Department of Pediatrics, Yale University School of Medicine, New Haven, CT \\ ${ }^{8}$ Sickle Cell Disease Research Center and Department of Pediatrics, College of Medicine, King \\ Saud University, Riyadh, Saudi Arabia.
}

\section{Abstract}

Sickle cell anemia is common in the Middle East and India where the HbS gene is sometimes associated with the Arab-Indian (AI) $\beta$-globin gene $(H B B)$ cluster haplotype. In this haplotype of sickle cell anemia, fetal hemoglobin $(\mathrm{HbF})$ levels are 3-4 fold higher than those found in patients with $\mathrm{HbS}$ haplotypes of African origin. Little is known about the genetic elements that modulate $\mathrm{HbF}$ in AI haplotype patients. We therefor studied Saudi HbS homozygotes with the AI haplotype (mean $\mathrm{HbF} 19.2 \pm 7.0 \%$, range 3.6 to 39.6\%) and known genotyped cis- and trans-acting elements associated with $\mathrm{HbF}$ expression. All cases, regardless of $\mathrm{HbF}$ concentration, were homozygous for AI haplotype-specific elements cis to $H B B$. SNPs in BCL11A and $H B S 1 L-M Y B$ that were associated with $\mathrm{HbF}$ in other populations explained only $8.8 \%$ of the variation of $\mathrm{HbF}$. KLF1 polymorphisms associated previously with high $\mathrm{HbF}$ were not present In the 44 patients tested. The SNPs and genetic loci we have chosen for this study do not explain the high HbF in sickle cell patients with AI haplotype or its variation among patients with this haplotype. The dispersion of $\mathrm{HbF}$ levels among AI haplotype patients suggests that other genetic elements modulate the effects of the known cis- and trans-acting regulators. These regulatory elements, which remain to be

\footnotetext{
(C) 2012 Elsevier Inc. All rights reserved.

Correspondence: Duyen Ngo, Department of Medicine, Boston University School of Medicine, 72 E. Concord St. Boston, MA 02118. duyen.ngo@bmc.org.

Publisher's Disclaimer: This is a PDF file of an unedited manuscript that has been accepted for publication. As a service to our customers we are providing this early version of the manuscript. The manuscript will undergo copyediting, typesetting, and review of the resulting proof before it is published in its final citable form. Please note that during the production process errors may be discovered which could affect the content, and all legal disclaimers that apply to the journal pertain.

Conflict-of Interest Disclosure: The authors declare no competing financial interests.
} 
discovered, might be specific in the Saudi and some other populations where HbF levels are especially high.

\section{Introduction}

Fetal hemoglobin $(\mathrm{HbF})$ protects against many of the hematologic and clinical complications of sickle cell anemia [[homozygosity for the sickle hemoglobin ( $\mathrm{HbS})$ gene; $H B B$ glu6val; reviewed in(1)]. This is dependent on the ability of $\mathrm{HbF}$ to hinder deoxyHbS polymerization. $\mathrm{HbF}$ level is variable among patients and populations with sickle cell anemia and is highly heritable. $(2,3) \mathrm{HbF}$ expression is regulated by elements linked to the $\beta$-globin gene $(H B B)$ gene cluster (11p15.5) and other quantitative trait loci (QTL) in trans to $H B B$, two of which are the $H B S 1 L-M Y B$ intergenic region on chromosome $6 \mathrm{q} 22-23$ and $B C L 11 A$ on chromosome 2p16.1. Together, these QTL accounted for 15 to $30 \%$ of $\mathrm{HbF}$ variation in sickle cell anemia patients with African origins of the sickle $\beta$-globin gene.(2, 4-8)

The HbS gene is also autochthonous to the Middle East and India where it is sometimes on an indigenous Arab-Indian (AI) $H B B$ globin gene cluster haplotype.(9-11) This haplotype is marked by an Xmn1 restriction site polymorphism (C>T 158 bp 5' to $H B G 2$; rs7482144) and other single nucleotide polymorphisms (SNPs) and insertion-deletion polymorphisms that distinguish it from all African-origin haplotypes, including the Senegal haplotype that also has the Xmn1 restriction site polymorphism. Individuals with sickle cell anemia and the AI haplotype had higher mean $\mathrm{HbF}$ levels [average 17\%, range 4-32\%, reviewed in(11)] than patients with $\mathrm{HbS}$ haplotypes of African origin.(12) For example, untreated African Americans had mean $\mathrm{HbF}$ levels of 5.8\% in males and 7.3\% in females with mean ages of about 17 years.(6) Because of their higher $\mathrm{HbF}$, AI haplotype sickle cell anemia patients had milder, albeit not asymptomatic disease when compared with carriers of African $H B B$ haplotypes. $(13,14)$ As the QTL modifying HbF levels in sickle cell anemia patients with the AI haplotype have not been comprehensively studied, we genotyped the major known $\mathrm{HbF}$ modulating QTL in 137 individuals and additional known cis- and trans-acting elements in subsets of these patients to study their association with $\mathrm{HbF}$.

\section{Methods}

Patients

Subjects with sickle cell anemia who attended clinics at King Fahd Hospital, Al-Ahsa and King Saud University, Riyadh, Saudi Arabia were selected on the basis of homozygosity for the $\mathrm{HbS}$ gene and the AI haplotype, age of at least 10 years; they were not taking hydroxyurea at the time $\mathrm{HbF}$ was measured. $\mathrm{HbF}$ was measured by high performance liquid chromatography (HPLC).

\section{HbS and the HBB haplotype}

Homozygosity for the $\mathrm{HbS}$ mutation was confirmed using amplification refractory mutation system analysis (Table S1).(15) The AI haplotype was ascertained by genotyping the $H B G 2$ Xmn1 C>T restriction site (rs7482144) and a Hinc2 site $5^{\prime}$ to $H B E 1$ (rs3834466), and confirmed by the presence of a $\mathrm{C}>\mathrm{T}$ polymorphism 68 bp $5^{\prime}$ to $H B D$.(16)

\section{Sanger sequencing/TaqMan assay of selected cis- and trans- regions to $\beta^{S}$-globin gene}

Polymorphisms in the $\beta$-globin gene cluster region were detected by Sanger sequencing or TaqMan assays in HbS homozygote with the Arab Indian haplotype. For many of these assays we selected a smaller group for testing. Selection was based on availability of 
samples at time of testing or at random from the subjects we had confirmed as homozygous for $\mathrm{HbS}$ and the AI haplotype.

HBB gene cluster regulatory regions (11p15): (Table S1)—Regions selected for sequencing were based on their potential functional role in globin gene regulation and included the $K L F 1$ binding site in the $H B B$ promoter region, an AT motif 530 bp $5^{\prime}$ to $H B B$, TTTTA repeats 1412 bp $5^{\prime}$ to $H B B$, the $H B D-H B G 1$ intergenic region, promoters of $H B G 2$ and $H B G 1$, and the cores of hypersensitive sites 2,3 and 4 (HS-2, 3, 4) of the $\beta$ globin gene cluster locus control region (LCR). A $-68 H B D C>\mathrm{T}$ SNP in the promoter of $H B D$ was detected using a custom designed TaqMan assay.

BCL11A, HBS1L-MYB, KLF1, DLX4-We genotyped SNPs in BCL11A and HBS1L$M Y B$ using either pre-made or custom TaqMan Assays (Applied Biosystems). As $K L F 1$ is a known regulator of $B C L 11 A$ and globin switching, and has been associated with the phenotype of hereditary persistence of HbF, and as BP1 ( $D L X 4)$ binds to AT motif $530 \mathrm{bp}$ $5^{\prime}$ to $H B B$ and has a down-regulatory effect on $H B B$ expression, we sequenced $K L F 1$ $(\mathrm{n}=44)$ and $B P 1(D L X 4)(\mathrm{n}=23)$ in randomly selected cases, to exclude polymorphisms in these genes that might be associated with HbF levels.(17)

\section{Statistical analysis}

Linear regression was performed on $\mathrm{HbF}$ for each genetic locus, adjusting for gender of the subjects. No transformation of the $\mathrm{HbF}$ values was necessary as the $\mathrm{HbF}$ values of these patients were approximately normally distributed. The analysis was performed using an additive genetic model whereby the total number of minor alleles present was counted for each subject. A 2-sample Kolmogorov-Smirnov test was used to compare the distribution of $\mathrm{HbF}$ in patients enrolled in Cooperative Study of Sickle Cell Disease (CSSCD) and in patients with the AI haplotype from Saudi Arabia.(18)

\section{Results \\ $\mathrm{HbF}$}

One hundred and thirty-seven sickle cell anemia patients who met our selection criteria were initially examined (Table 1) and their distribution of $\mathrm{HbF}$ concentrations is shown in Figure 1. Mean $\mathrm{HbF}$ was $19.2 \pm 7.0 \%$. For comparison, African Americans with sickle cell anemia had a mean $\mathrm{HbF}$ of $6.6 \pm 5.5 \%$. The $\mathrm{HbF}$ distribution for African Americans with sickle cell anemia was right skewed, whereas the AI haplotype subjects had a Gaussian or normal distribution. The distributions of $\mathrm{HbF}$ in these 2 cohorts were significantly different (p-value 2.2e-16).

\section{Sanger sequencing/TaqMan assays}

BCL11A and HBS1L-MYB-Table 2 shows the associations of polymorphisms in $B C L 11 A$ and the HBS1L-MYB intergenic region and $\mathrm{HbF}$ in 137 patients. The $2.9 \mathrm{~kb}$ region in the $2^{\text {nd }}$ intron of $B C L 11 A$ bounded by rs 1427407 and rs 4671393 was associated with $\mathrm{HbF}$ as suggested previously (4-8), but accounted for only $7.5 \%$ of the variation in $\mathrm{HbF}$. Together, BCL11A and $H B S 1 L-M Y B$ accounted for $8.8 \%$ of $\mathrm{HbF}$ variance. The remaining polymorphisms we examined were done in subsets of these patients.

$H B B-H B D$ intergenic region-Mutations within $H B B-H B D$ region have been linked to elevated $\operatorname{HbF} .(17,19)$ We investigated polymorphisms within this region to further characterize the AI haplotype and to identify candidates that may be associated with elevated $\mathrm{HbF}$. An AT motif, $(\mathrm{AC})_{2}(\mathrm{AT})_{9}(\mathrm{~T})_{5}, 530 \mathrm{bp} 5^{\prime}$ to $H B B$ is found with the AI 
haplotype and postulated to play a role in ameliorating the sickle phenotype due to suppression of $H B B$ by binding the repressor protein BP1.(17) In 6 AI haplotype homozygotes that we examined, all had the previously described AI haplotype AT repeat motif. (17)

In 35 patients, the (TTTTA) 6 insertion $1412 \mathrm{bp} 5^{\prime}$ of $H B B$ was present . In previous studies, Benin haplotype cases were reported to have a (TTTTA) $)_{5}$ insertion (rs61168339; Table 3).

In 6 cases with a mean $\mathrm{HbF}$ level of $24.5 \%$, the sequence of the KLF1 binding site in the $H B B$ promoter (CCACACCCT) was identical to the reference sequence (GenBank U01317) suggesting a lack of novel polymorphisms that could account for the uniquely elevated $\mathrm{HbF}$ found in the AI haplotype.

A C> T SNP 68 bp $5^{\prime}$ to $H B D$ that we previously found to be a specific marker for the AI haplotype was homozygous in all 137 cases.(16)

HBG1 and HBG2 promoters-Thirty patients were screened for promoter mutations. One polymorphism, a C>G 369 bp $5^{\prime}$ to $H B G 1$ (rs2855040), was identified in the $H B G 1$ promoter region and a $4 \mathrm{bp}$ (AAGC) insertion at $222 \mathrm{bp} 5^{\prime}$ to $H B G 1$ was found. These findings are not unique to sickle patients with the AI haplotype and are therefore unlikely to have a significant role in modulating the elevated $\mathrm{HbF}$ that distinguishes the $\mathrm{AI}$ haplotypes from other $H B B$ haplotypes. The $H B G 2$ promoter contained the Xmn1 polymorphism, $\mathrm{C}>\mathrm{T}$ SNP 158 bp $5^{\prime}$ to $H B G 2$ (rs7482144), which is a marker for the AI haplotype.

LCR core regions of HS-2, 3, and 4-Thirty patients were studied. The core regions of HS-3 and HS-4 were identical to the GenBank U01317 reference sequences. In the core of HS-2, the unique TA $)_{10}(\mathrm{CA})_{2}(\mathrm{TA})_{2} \mathrm{CG}(\mathrm{TA})_{12}$ motif known to be typical of the AI haplotype, was present.

KLF1-Forty-four cases with $\mathrm{HbF}$ levels between 9 and 30\% were studied. Table 4 shows the $\mathrm{HbF}$ levels and the SNPs detected in $K L F 1$ exons. None of the SNPs in $K L F 1$ we studied showed an association with elevated $\mathrm{HbF}$ in AI haplotype patients and the polymorphisms we detected were "neutral." SNPs previously associated with increased HbF were not present.(20-22) There was no significant difference in HbF level between the 12 patients, who were heterozygous for the promoter $\mathrm{nt}-188 \mathrm{C}>\mathrm{G}$ polymorphism (rs3817621) and had $\mathrm{HbF}$ of $13.2 \pm 6.8 \%$, compared with the 10 cases without the same promoter polymorphism with $\mathrm{HbF}$ of $16.4 \pm 4.5 \%$.

DLX4 (BP1)—Twenty-three patients were studied: 4 were heterozygous for SNP rs58769681 (G>A) in the 5'UTR of $D L X 4 ; 2$ were heterozygous for rs61749026 (A>G; $\mathrm{N} 44 \mathrm{~S}$ ); no mutation was present in the remaining 17 patients.

\section{Discussion}

The distribution of $\mathrm{HbF}$ concentrations in AI haplotype sickle cell anemia was significantly different than that of patients with African-derived $H B B$ haplotypes suggesting differential regulation of $H B G 2$ and $H B G 1$ in these genetically distinct populations (Figure 1). We genotyped the known cis- and trans-acting elements associated with $\mathrm{HbF}$ regulation to try and explain these differences.

\section{Cis-acting elements}

Unique polymorphisms cis to $H B B$ and associated with the $\mathrm{HbS}$ gene distinguish the AI from other haplotypes. Every patient was homozygous for the cis-acting elements we 
examined suggesting that although these elements are linked to the sequences, or are the sequences causing high levels of expression of the $\gamma$-globin genes, they alone cannot account for the heterogeneity of $\mathrm{HbF}$ among AI haplotype carriers.

We confirmed the presence of the $(\mathrm{AC})_{2}(\mathrm{AT})_{9}(\mathrm{~T})_{5}$ motif in the $H B B-H B D$ intergenic region. This is a binding site for BP1 $(D L X 4)$, which binds more tightly to this region in the AI haplotype compared with other haplotypes, and reduces $\beta^{\mathrm{S}}$-globin gene expression.(17, 23) This particular AT repeat motif was associated with the lowest $H B B$ mRNA expression in differentiated MEL cells.(24) A similar AT motif was associated with $\beta$ thalassemia in carriers without a detectable mutation in $H B B .(25,26) H B B$ suppression might play a role in the high level of $\gamma$-globin gene expression found with the AI haplotype. The (TTTTA) 6 insertion 1412 bp upstream of $H B B$ is also seen with the AI haplotype but the functional significance of this insertion/deletion polymorphism is unknown.(27) Functional studies may help to clarify whether the differences in the copy number of this motif can explain the $\mathrm{HbF}$ difference between these two $H B B$ haplotypes.

The discovery of the Corfu $\delta \beta$ thalassemia deletion first suggested that the $H B D-H B G 1$ intergenic region had a potential role in activating the $\gamma$-globin genes and repressing the downstream $\beta$-globin gene.(19) A $3.5 \mathrm{~kb}$ region near the $5^{\prime}$ portion of $H B D$ binds the $H B G$ silencer BCL11A, GATA-1 and HDAC1. Its deletion delayed $H B G$ to $H B B$ switching.(28) A functional C $>\mathrm{T}$ SNP $68 \mathrm{bp} 5^{\prime}$ to $H B D$ that is a specific marker for the AI haplotype was previously reported; whether this affects $H B G$ expression is unknown.(16)

The $-158 \mathrm{C}>\mathrm{T}$ SNP (rs7482144) is present in the AI haplotype and is associated with high $H B G 2$ expression in this haplotype and the African-derived Senegal haplotype. However, the functional role of this polymorphism is ill-defined. $(29,30)$ Variation in HS-2 of the LCR has been reported to be associated with HbF levels in sickle cell anemia.(31) Further studies are needed to clarify whether or not the HS-2 signature sequence found in the AI haplotype plays a role in $\gamma$-globin gene regulation.

\section{Trans-acting elements}

QTL on chr6q22-23 (HBS1L-MYB)(32, 33) and chr2p16.1 (BCL11A) $(2,4,6,34)$ modulate $H B G$ expression in all populations studied, albeit with different effect sizes. SNPs in these loci accounted for 15 to $30 \%$ of the $\mathrm{HbF}$ phenotypic variation in African American sickle cell anemia. $(2,4-7,35)$ Among AI haplotype homozygotes, variants in $B C L 11 A$ accounted for $7.5 \%$ of $\mathrm{HbF}$ variance. SNPs in $H B S 1 L-M Y B$ that have been associated with $\mathrm{HbF}$ level in other populations were not associated with $\mathrm{HbF}$ in the AI haplotype. However the minor allele frequencies of these $H B S 1 L-M Y B$ SNPs were about $1 \%$ so that a SNP of importance is likely to be rare and have a small effect in this population. It remains possible that AI haplotype patients with high $\mathrm{HbF}$ have novel functional in $B C L 11 A$ and $H B S 1 L$ $M Y B$ that are not tracked by the SNPs we genotyped. Alternatively, SNPs in these genes play a lesser role in $\mathrm{HbF}$ variance in the AI haplotype than in African haplotypes.

$K L F 1$, a regulator of $B C L 11 A$, also mediates hemoglobin switching. $(22,36)$ Its polymorphisms have been associated with the phenotype of hereditary persistence of $\mathrm{HbF}$. $(20,22,37)$ We did not find mutations in the $K L F 1$ zinc finger domains that were previously associated with increased $\mathrm{HbF}$ in the 44 cases we studied for these polymorphisms. The SNPs that were present did not show a correlation with $\mathrm{HbF}$ in the AI haplotype patients we studied, and were likely to be "neutral." Although a few SNPs were found in BP1 (DLX4) in some patients, their role in $\mathrm{HbF}$ regulation is unclear.

Rarely, African American HbS homozygotes can have a baseline HbF similar to that associated with the AI haplotype. These individuals more commonly have the minor alleles 
of $B C L 11 A$ and the $H B S 1 L-M Y B$ intergenic region compared with counterparts with low HbF.(38) In some instances, rare missense mutations in $M Y B$ have been associated with higher HbF in African Americans with sickle cell anemia.(2) We did not test these specific variants in AI haplotype patients.

\section{Conclusions}

To increase our understanding of $\mathrm{HbF}$ regulation in AI haplotype HbS homozygotes we compared polymorphisms in selected regions that define this haplotype and also examined known trans acting elements associated with $\mathrm{HbF}$ expression. Although all polymorphisms were not studied in all patients, previous studies of the AI haplotype and our results suggest that any variants in these sequences that might be detected if a larger patient sample were to be examined are apt to be rare.

$\mathrm{HbF}$ levels are determined by interactions of cis and trans acting elements and are likely to be, modulated by stress erythropoiesis. $(39,40)$ Carriers of the AI haplotype and sickle cell trait have nearly normal $\mathrm{HbF}$ levels(11) suggesting that homozygosity for the AI haplotype and/or the presence of hemolytic anemia is required for the clinical expression of the high $\mathrm{HbF}$ phenotype. Some elements cis to $H B B$ in the AI haplotype, like the -530 AT motif, down-regulate $H B B$; others, such as the $-68 \mathrm{C}>\mathrm{T} H B D$ promoter SNP might down regulate $H B D$ expression. $(16,17)$ Coupled with continued expression of $H B G 2$, this might reduce post-transcriptional competition and enhance the stability of $\gamma$-globin RNA. $(41,42)$ Known trans-acting QTL accounted for only $8.8 \%$ of $\mathrm{HbF}$ variance in this population and SNPs in $B C L 11 A$ explained only $7.5 \%$ of the variance, or about half that found in the largest reported study of African-origin patients. (4) Additional QTL could have evolved in the Arab population and might be discovered by sufficiently powered genome-wide association studies or by whole genome sequencing of highly selected patients. Determining transcription factor binding patterns and histone modification in the $H B B$ gene cluster region in AI haplotype cases could provide a better understanding of the influence of different cis acting elements on $\mathrm{HbF}$ globin gene expression.

The variation in $\mathrm{HbF}$ among patients with the AI haplotype suggests that other genetic elements modulate the effects of the known cis- and trans-acting regulators. These regulatory elements, which remain to be discovered, might be specific for the Saudi and some other populations where $\mathrm{HbF}$ levels are especially high.

\section{Supplementary Material}

Refer to Web version on PubMed Central for supplementary material.

\section{Acknowledgments}

Supported by R01 HL 068970, RC2 HL 101212 and R01 87681 and King Abdulaziz City for Science and Technology (KACST ARP-30-367)

\section{References}

1. Steinberg MH, Sebastiani P. Genetic modifiers of sickle cell disease. Am. J. Hematol. 2012; 87:795-803. [PubMed: 22641398]

2. Galarneau G, Palmer CD, Sankaran VG, Orkin SH, Hirschhorn JN, Lettre G. Fine-mapping at three loci known to affect fetal hemoglobin levels explains additional genetic variation. Nat. Genet. 2010; 42:1049-51. [PubMed: 21057501]

3. Dover GJ, Boyer SH, Charache S, Heintzelman K. Individual variation in the production and survival of F cells in sickle-cell disease. N. Engl. J. Med. 1978; 299:1428-35. [PubMed: 101847] 
4. Lettre G, Sankaran VG, Bezerra MA, Araujo AS, Uda M, Sanna S, et al. DNA polymorphisms at the BCL11A, HBS1L-MYB, and beta-globin loci associate with fetal hemoglobin levels and pain crises in sickle cell disease. Proc. Natl. Acad. Sci. U.S.A. 2008; 105:11869-74. [PubMed: 18667698]

5. Bae HT, Baldwin CT, Sebastiani P, Telen MJ, Ashley-Koch A, Garrett M, et al. Meta-analysis of 2040 sickle cell anemia patients: BCL11A and HBS1L-MYB are the major modifiers of HbF in African Americans. Blood. 2012; 120:1961-2. [PubMed: 22936743]

6. Solovieff N, Milton JN, Hartley SW, Sherva R, Sebastiani P, Dworkis DA, et al. Fetal hemoglobin in sickle cell anemia: genome-wide association studies suggest a regulatory region in the $5^{\prime}$ olfactory receptor gene cluster. Blood. 2010; 115:1815-22. [PubMed: 20018918]

7. Sedgewick A, Timofeev N, Sebastiani P, So JCC, Ma ESK, Chan LC, et al. BCL11A (2p16) is a major $\mathrm{HbF}$ quantitative trait locus in three different populations. Blood Cells, Mol. Dis. 2008; 41:255-8. [PubMed: 18691915]

8. Makani J, Menzel S, Nkya S, Cox SE, Drasar E, Soka D, et al. Genetics of fetal hemoglobin in Tanzanian and British patients with sickle cell anemia. Blood. 2011; 117:1390-2. [PubMed: 21068433]

9. Labie D, Srinivas R, Dunda O, Dode C, Lapoumeroulie C, Devi V, et al. Haplotypes in tribal Indians bearing the sickle gene: evidence for the unicentric origin of the beta $\mathrm{S}$ mutation and the unicentric origin of the tribal populations of India. Hum. Biol. 1989; 61:479-91. [PubMed: 2480325]

10. Kulozik AE, Wainscoat JS, Serjeant GR, Kar BC, Al-Awamy B, Essan GJF, et al. Geographical survey of the ás-globin gene haplotypes: Evidence for an independent Asian origin of the sicklecell mutation. Am. J. Hum. Genet. 1986; 39:239-44. [PubMed: 3752087]

11. Miller BA, Salameh M, Ahmed M, Wainscoat J, Antognetti G, Orkin S, et al. High fetal hemoglobin production in sickle cell anemia in the eastern province of Saudi Arabia is genetically determined. Blood. 1986; 67:1404-10. [PubMed: 2421808]

12. Akinsheye I, Alsultan A, Solovieff N, Ngo D, Baldwin CT, Sebastiani P, et al. Fetal hemoglobin in sickle cell anemia. Blood. 2011; 118:19-27. [PubMed: 21490337]

13. Adekile AD. Limitations of $\mathrm{Hb} \mathrm{F}$ as a phenotypic modifier in sickle cell disease: study of Kuwaiti Arab patients. Hemoglobin. 2011; 35:607-17. [PubMed: 21999156]

14. El-Hazmi MAF. Clinical and haematological diversity of sickle cell disease in Saudi children. J. Trop. Pediatr. 1992; 38:106-12. [PubMed: 1380566]

15. Little S. Amplification-refractory mutation system (ARMS) analysis of point mutations. Curr. Protoc. Hum. Genet. May.2001 Chapter 9:Unit 98.

16. Alsultan A, Ngo DA, Farrell JJ, Akinsheye I, Solovieff N, Ghabbour HA, et al. A functional promoter polymorphism of the delta-globin gene is a specific marker of the Arab-Indian haplotype. Am. J. Hematol. 2012; 87:824-6. [PubMed: 22641479]

17. Elion J, Berg PE, Lapoumeroulie C, Trabuchet G, Mittelman M, Krishnamoorthy R, et al. DNA sequence variation in a negative control region $5^{\prime}$ to the beta-globin gene correlates with the phenotypic expression of the beta s mutation. Blood. 1992; 79:787-92. [PubMed: 1346253]

18. Massey FJJ. The Kolmogorov-Smirnov test for goodness of fit. J. Am. Stat. Assoc. 1951; 46:6878.

19. Chakalova L, Osborne CS, Dai YF, Goyenechea B, Metaxotou-Mavromati A, Kattamis A, et al. The Corfu deltabeta thalassemia deletion disrupts gamma-globin gene silencing and reveals posttranscriptional regulation of HbF expression. Blood. 2005; 105:2154-60. [PubMed: 15536151]

20. Borg J, Papadopoulos P, Georgitsi M, Gutierrez L, Grech G, Fanis P, et al. Haploinsufficiency for the erythroid transcription factor KLF1 causes hereditary persistence of fetal hemoglobin. Nat. Genet. 2010; 42:801-5. [PubMed: 20676099]

21. Zhou D, Liu K, Sun CW, Pawlik KM, Townes TM. KLF1 regulates BCL11A expression and gamma- to beta-globin gene switching. Nat. Genet. 2010; 42:742-4. [PubMed: 20676097]

22. Borg J, Patrinos GP, Felice AE, Philipsen S. Erythroid phenotypes associated with KLF1 mutations. Haematologica. 2011; 96:635-8. [PubMed: 21531944]

23. Mpollo MS, Beaudoin M, Berg PE, Beauchemin H, D'Agati V, Trudel M. BP1 is a negative modulator of definitive erythropoiesis. Nucl. Acids Res. 2006; 34:5232-7. [PubMed: 17003054] 
24. Chan PK, Ma ES, Philipsen S, Tan-Un KC. The study of sequence configuration and functional impact of the (AC)n(AT)xTy motif in human beta-globin gene promoter. Am. J. Hematol. 2007; 82:342-8. [PubMed: 17133428]

25. Semenza GL, Delgrosso K, Poncz M, Malladi P, Schwartz E, Surrey S. The silent carrier allele: beta thalassemia without a mutation in the beta-globin gene or its immediate flanking regions. Cell. 1984; 39:123-8. [PubMed: 6091904]

26. Murru S, Loudianos G, Cao A, Vaccargiu S, Pirastu M, Sciarratta GV, et al. A beta-thalassemia carrier with normal sequence within the beta-globin gene. Blood. 1990; 76:2164-5. [PubMed: 2242438]

27. Spritz RS. Duplication/deletion polymorphism $5^{\prime}$ - to the human beta globin gene. Nucl. Acids Res. 1981; 9:5037-47. [PubMed: 7312624]

28. Sankaran VG, Xu J, Byron R, Greisman HA, Fisher C, Weatherall DJ, et al. A functional element necessary for fetal hemoglobin silencing. N. Engl. J. Med. 2011; 365:807-14. [PubMed: 21879898]

29. Miller BA, Salameh M, Ahmed M, Olivieri N, Antognetti G, Orkin SH, et al. Analysis of hemoglobin F production in Saudi Arabian families with sickle cell anemia. 1987; 70:716-20.

30. Miller BA, Olivieri N, Salameh M, Ahmed M, Antognetti G, Huisman TH, et al. Molecular analysis of the high-hemoglobin-F phenotype in Saudi Arabian sickle cell anemia. N. Engl. J. Med. 1987; 316:244-50. [PubMed: 2432426]

31. Oner C, Dimovski AJ, Altay C, Gurgey A, Gu YC, Huisman TH, et al. Sequence variations in the $5^{\prime}$ hypersensitive site- 2 of the locus control region of beta $\mathrm{S}$ chromosomes are associated with different levels of fetal globin in hemoglobin S homozygotes. 1992; 79:813-9.

32. Creary LE, Ulug P, Menzel S, McKenzie CA, Hanchard NA, Taylor V, et al. Genetic variation on chromosome 6 influences F cell levels in healthy individuals of African descent and HbF levels in sickle cell patients. PLoS One. 2009; 4:e4218. [PubMed: 19148297]

33. Thein SL, Menzel S, Peng X, Best S, Jiang J, Close J, et al. Intergenic variants of HBS1L-MYB are responsible for a major quantitative trait locus on chromosome $6 \mathrm{q} 23$ influencing fetal hemoglobin levels in adults. Proc. Natl. Acad. Sci. U.S.A. 2007; 104:11346-51. [PubMed: 17592125]

34. Uda M, Galanello R, Sanna S, Lettre G, Sankaran VG, Chen W, et al. Genome-wide association study shows BCL11A associated with persistent fetal hemoglobin and amelioration of the phenotype of beta-thalassemia. Proc. Natl. Acad. Sci. U.S.A. 2008; 105:1620-5. [PubMed: 18245381]

35. Thein SL, Menzel S, Lathrop M, Garner C. Control of fetal hemoglobin: new insights emerging from genomics and clinical implications. Hum, Mol, Genet. 2009; 18:R216-R23. [PubMed: 19808799]

36. Siatecka M, Bieker JJ. The multifunctional role of EKLF/KLF1 during erythropoiesis. Blood. 2011; 118:2044-54. [PubMed: 21613252]

37. Gallienne AE, Dreau HM, Schuh A, Old JM, Henderson S. Ten novel mutations in the erythroid transcription factor KLF1 gene associated with increased fetal hemoglobin levels in adults. Haematologica. 2012; 97:340-3. [PubMed: 22102705]

38. Akinsheye I, Solovieff N, Ngo D, Malek A, Sebastiani P, Steinberg MH, et al. Fetal hemoglobin in sickle cell anemia: Molecular characterization of the unusually high fetal hemoglobin phenotype in African Americans. Am. J. Hematol. 2012; 87:217-219. [PubMed: 22139998]

39. Stamatoyannopoulos G. Control of globin gene expression during development and erythroid differentiation. Exp. Hematol. 2005; 33:259-71. [PubMed: 15730849]

40. Mabaera R, West RJ, Conine SJ, Macari ER, Boyd CD, Engman CA, et al. A cell stress signaling model of fetal hemoglobin induction: what doesn't kill red blood cells may make them stronger. Exp. Hematol. 2008; 36:1057-72. [PubMed: 18718415]

41. Russell JE. A post-transcriptional process contributes to efficient gamma-globin gene silencing in definitive erythroid cells. Eur. J. Haematol. 2007; 79:516-25. [PubMed: 17976188]

42. Dover GJ, Boyer SH. Fetal hemoglobin-containing cells have the same mean corpuscular hemoglobin as cells without fetal hemoglobin: a reciprocal relationship between gamma- and beta- 
globin gene expression in normal subjects and in those with high fetal hemoglobin production. Blood. 1987; 69:1109-13. [PubMed: 2435342] 

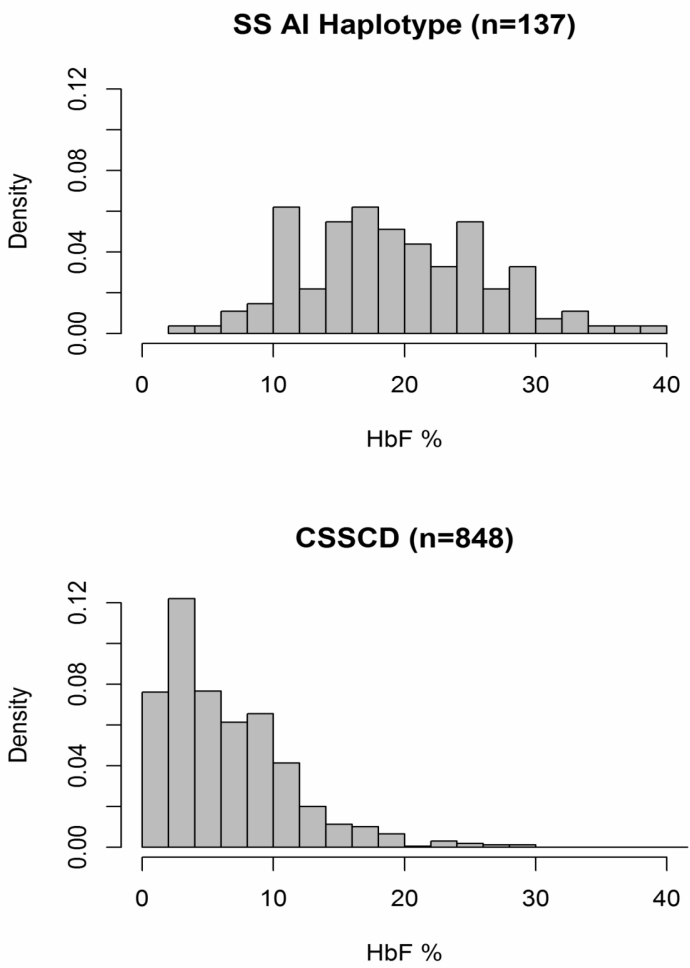

Figure 1. Density plots showing the distribution of $\mathrm{HbF}$ in sickle cell anemia with the AI haplotype (SS AI Haplotype)

For comparison, results from the Cooperative Study of Sickle Cell Disease (CSSCD), an African American sickle cell anemia population are replotted.(6) All CSSCD subjects were aged $\geq 5$ years and none were taking hydroxyurea. These distributions are significantly different $(\mathrm{p}=2.2 \mathrm{e}-16)$. 


\section{Table 1}

A comparison of age and $\mathrm{HbF}$ in patients with sickle cell anemia (HbSS) and the Arab-Indian (AI) haplotype.

\begin{tabular}{|l|c|c|c|c|c|c|c|}
\hline & \multicolumn{3}{|c|}{ HbSS AI Haplotype } & \multicolumn{3}{c|}{$\begin{array}{c}\text { CSSCD } \\
\text { n= 848 }\end{array}$} & \\
\hline Category & Mean & SD & Range & Mean & SD & Range & P-value \\
\hline Age $(\mathrm{yrs})$ & 26.6 & 10.6 & $11-65$ & 17.2 & 10.7 & $5-63$ & $<0.001$ \\
\hline $\mathrm{HbF}(\%)$ & 19.2 & 7.0 & $3.6-39.6$ & 6.6 & 5.5 & $0.1-60$ & $<0.001$ \\
\hline
\end{tabular}

Patients with sickle cell anemia from the Cooperative Study of Sickle Cell Database (CSSCD) served as reference in the statistical analysis. Although the CSSCD cohort was slightly younger on average, the $\mathrm{HbF}$ difference remains significant as age has an inverse relationship with $\mathrm{HbF}$. Only subjects age 10 or older were included in this analysis as $\mathrm{HbF}$ changes are minimal after that age cutoff. 
Table 2

Quantitative trait loci (QTLs) and association with HbF in subjects homozygous for HbS with Arab-Indian haplotype.

\begin{tabular}{lllccccccc}
\hline & & & & & \multicolumn{3}{c}{ SS AI Haplotype (n=137) } \\
\cline { 6 - 9 } Gene & SNP & $\begin{array}{l}\text { Chr. } \\
\text { Position }\end{array}$ & $\begin{array}{c}\text { Major } \\
\text { Allele }\end{array}$ & $\begin{array}{c}\text { Minor } \\
\text { Allele }\end{array}$ & MAF & Beta & SE & P \\
\hline BCL11A & rs6732518 & 60708847 & $\mathrm{C}$ & $\mathrm{T}$ & 0.463 & 1.280 & 0.827 & 0.124 \\
BCL11A & rs1427407 & 60718293 & $\mathrm{G}$ & $\mathrm{T}$ & 0.283 & 2.451 & 0.891 & $0.007^{*}$ \\
BCL11A & rs766432 & 60719970 & $\mathrm{~A}$ & $\mathrm{C}$ & 0.300 & 2.769 & 0.864 & $0.002^{*}$ \\
BCL11A & rs11886868 & 60720496 & $\mathrm{~T}$ & $\mathrm{C}$ & 0.455 & 1.773 & 0.807 & $0.030^{*}$ \\
BCL11A & rs4671393 & 60721201 & $\mathrm{G}$ & $\mathrm{A}$ & 0.301 & 2.697 & 0.859 & $0.002^{*}$ \\
BCL11A & rs6729815 & 60723922 & $\mathrm{~T}$ & $\mathrm{C}$ & 0.471 & -0.161 & 0.843 & 0.849 \\
HMIP & rs7775698 & 135418385 & $\mathrm{G}$ & $\mathrm{A}$ & 0.056 & -0.991 & 1.811 & 0.585 \\
HMIP & rs9399137 & 135418768 & $\mathrm{~T}$ & $\mathrm{C}$ & 0.073 & 1.358 & 1.621 & 0.404 \\
HMIP & rs4895441 & 135426323 & $\mathrm{~A}$ & $\mathrm{G}$ & 0.090 & 0.703 & 1.593 & 0.660 \\
HMIP & rs9402686 & 135427567 & $\mathrm{G}$ & $\mathrm{A}$ & 0.091 & 0.699 & 1.489 & 0.640 \\
HMIP & rs73555746 & 135521239 & $\mathrm{~A}$ & $\mathrm{C}$ & 0.004 & 5.583 & 7.085 & 0.432 \\
\hline
\end{tabular}

QTLs found to be significantly associated with $\mathrm{HbF}$ are denoted with *. MAF = minor allele frequency; Beta $=$ effect size on $\mathrm{HbF}$ levels; $\mathrm{SE}=$ standard error; $\mathrm{P}=\mathrm{p}$-value. 


\section{Table 3}

Polymorphisms in globin gene cluster region detected by Sanger sequencing or TaqMan assays in homozygous sickle cell anemia patients with the Arab Indian haplotype.

\begin{tabular}{|c|c|}
\hline $\begin{array}{l}\text { Location or Gene } \\
\text { (\# screened) }\end{array}$ & Polymorphism or Sequence \\
\hline \multicolumn{2}{|c|}{$H B B-H B D$ intergenic region } \\
\hline$-5305^{\prime}$ to $H B B(6)$ & $(\mathrm{AC})_{2}(\mathrm{AT})_{9} \mathrm{~T}_{5}$ \\
\hline$-14125^{\prime}$ to $H B B(35)$ & G(TTTTA) ${ }_{6}$ TTTTG \\
\hline \multicolumn{2}{|c|}{$H B D-H B G 1$ intergenic region } \\
\hline$-685^{\prime}$ to $H B D(137)$ & $\mathrm{C}>\mathrm{T}$ \\
\hline \multicolumn{2}{|l|}{$H B G 1$ promoter } \\
\hline$-2225^{\prime}$ to $H B G 1(30)$ & AAGC insertion \\
\hline \multicolumn{2}{|l|}{$H B G 2$ promoter } \\
\hline$-1585^{\prime}$ to $H B G 2(137)$ & $\mathrm{C}>\mathrm{T}$ \\
\hline \multicolumn{2}{|l|}{ LCR } \\
\hline HS-2 Core (30) & $(\mathrm{TA})_{10}(\mathrm{CA})_{2}(\mathrm{TA})_{2} \mathrm{CG}(\mathrm{TA})_{12}$ \\
\hline
\end{tabular}


Table 4

$K L F 1$ polymorphisms in sickle cell anemia.

\begin{tabular}{|c|c|c|c|c|c|c|c|c|c|}
\hline \multicolumn{2}{|c|}{ M39L } & \multicolumn{2}{|c|}{ S102P } & \multicolumn{2}{|c|}{ F182L } & \multirow[t]{2}{*}{ Number } & \multirow{2}{*}{$\begin{array}{c}\text { Gender } \\
(\mathbf{M} / \mathbf{F})\end{array}$} & \multirow{2}{*}{$\begin{array}{c}\text { Age (yrs.) } \\
(\text { Mean } \pm \text { SD })\end{array}$} & \multirow{2}{*}{$\begin{array}{c}\text { HbF } \\
(\text { Mean } \pm \text { SD })\end{array}$} \\
\hline homo & hetero & homo & hetero & homo & hetero & & & & \\
\hline - & - & + & - & - & - & 2 & $1 / 1$ & $17.5 \pm 2.1$ & $15.3 \pm 5.2$ \\
\hline - & - & - & + & - & - & 17 & $11 / 6$ & $26.2 \pm 10.4$ & $16.3 \pm 7.2$ \\
\hline- & + & - & + & - & - & 3 & $1 / 2$ & $30 \pm 10.5$ & $9.3 \pm 0.6$ \\
\hline- & - & - & + & - & + & 2 & $0 / 2$ & $37 \pm 24$ & $26.1 \pm 4.0$ \\
\hline- & - & + & - & - & + & 1 & $0 / 1$ & 25 & 23 \\
\hline- & - & - & - & - & - & 18 & $11 / 7$ & $24.8 \pm 7.3$ & $15.6 \pm 5.1$ \\
\hline
\end{tabular}

S102P: T>C (rs2072597); M39L: A>C (rs112631212); F182L: T>C (rs2072596) 